\title{
Changes of Information Professional Roles and Initiatives to Support Information Management
}

Wilmina Lee, Norhayati Hussin, Amzari Abu Bakar, Aniza Jamaluddin, Marlia Idrus, Norshila Shaifuddin, Mohd Yusof Mustaffar

To Link this Article: http://dx.doi.org/10.6007/IJARBSS/v10-i11/9073 DOI:10.6007/IJARBSS/v10-i11/9073

Received: 10 September 2020, Revised: 14 October 2020, Accepted: 18 November 2020

Published Online: 29 November 2020

In-Text Citation: (Wilmina Lee et al., 2020)

To Cite this Article: Wilmina Lee, N. H., Bakar, A. A., Jamaluddin, A., Idrus, M., Shaifuddin, N., \& Mustaffar, M. Y. (2020). Changes of Information Professional Roles and Initiatives to Support Information Management. International Journal of Academic Research in Business and Social Sciences, 10(11), 1475-1482.

Copyright: (c) 2020 The Author(s)

Published by Human Resource Management Academic Research Society (www.hrmars.com) This article is published under the Creative Commons Attribution (CC BY 4.0) license. Anyone may reproduce, distribute, translate and create derivative works of this article (for both commercial and non-commercial purposes), subject to full attribution to the original publication and authors. The full terms of this license may be seen at: http://creativecommons.org/licences/by/4.0/legalcode

Vol. 10, No. 11, 2020, Pg. 1475 - 1482

Full Terms \& Conditions of access and use can be found at http://hrmars.com/index.php/pages/detail/publication-ethics 


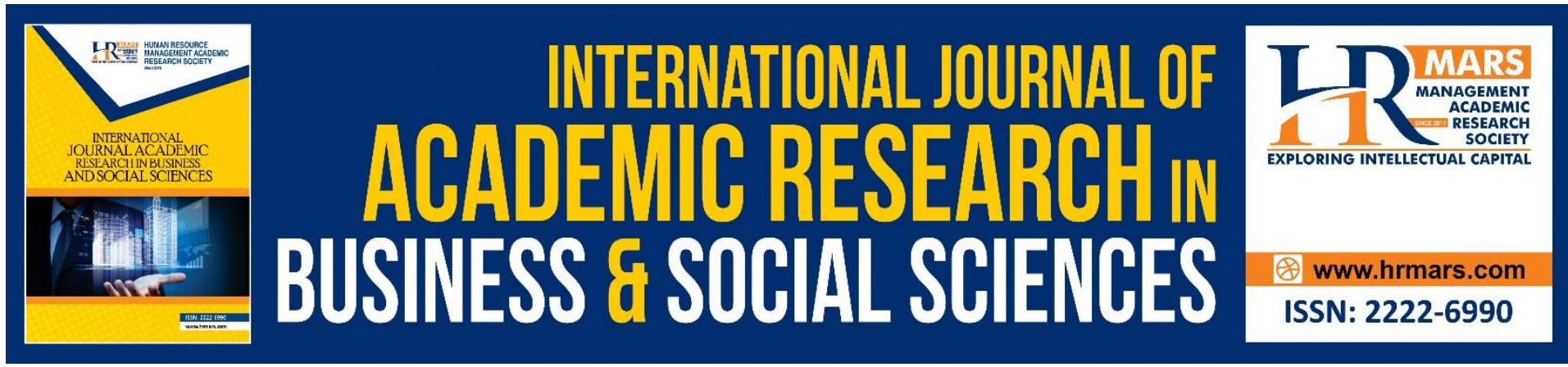

\title{
Changes of Information Professional Roles and Initiatives to Support Information Management
}

\author{
${ }^{1}$ Wilmina Lee, ${ }^{2}$ Norhayati Hussin, ${ }^{2}$ Amzari Abu Bakar, ${ }^{2}$ Aniza \\ Jamaluddin, ${ }^{2}$ Marlia Idrus, ${ }^{2}$ Norshila Shaifuddin, ${ }^{2}$ Mohd Yusof \\ Mustaffar \\ ${ }^{1}$ Taylor's Library, Taylor`s Lakeside Campus, Selangor, Malaysia, ${ }^{2}$ Faculty of \\ Information Management, Universiti Teknologi MARA (UiTM) Selangor, Malaysia
}

\begin{abstract}
Information professionals (IP) such as librarian, archivists, information managers, information systems specialists, and records managers play an important role in the information era to influence and inspire their users to understand and choose the right information that acquire from various resources to be used appropriately according to their nature of business. These few years, the roles of information professionals especially Librarian, have been discussed and reviewed. Thus, the similar intention of this paper is to access and explore the initiation and enhancement activities by the information professionals to support the information management in their organizations that will benefit to the department and organization. The efficient and effective information management in the organization will contribute and influence the organizational performance, including improved efficiency \& productivity, better decision making, effective record management and better policy and planning. In the academic aspect, the initiative by information professional may contribute to the higher ranking of the universities or college.
\end{abstract}

Keyword: Library and Information Management, Information Professional, Professional Roles, Information Professional Initiatives

\section{Introduction}

The fast evolvement of the technologies nowadays causing a tremendous change in the way we do things and what we need to know, so as well of the profession within the information management fields. This is due to the development of the technologies that potentially replicate information professional jobs. Innovations have been developed in a sense to smoothen the information professional work process and to support their activities in delivering and disseminating the information, however at the same seen as a threat to them. Other stakeholders who may work closely with the professional information fields will familiarize themselves with the nature of the job as an information professional, the process flow and maybe seen the opportunities and investment outcome to take over the information professional roles and responsibilities. At the IFLA 2018 held in Kuala Lumpur in most the networking session with the participant, it was discussed among them on the relevance of the 
Librarian especially to the communities nowadays with the rapid development of technologies, and how librarians will need to maintain their credibility as the professional in managing and handling the information compared to others. Lord (2014) agreed that the information professional is struggling to prove their capabilities and value to the communities' impact of the big data phenomenon, furthermore, with the dynamic change of business, that requires an organization to cut a manpower cost due to the restructuring of the organization. Yamazaki (2007) has listed out the trend of changes that require attention from the information professional in maintaining their credibility that are; the tremendous usage of the internet worldwide, the huge growth of information and knowledge created through the web, the accessibility of the information without a need to visit the physical library and consulting the information professional to get the information and the enhancement of the value of information in daily life.

\section{Changes of Information Professional Roles and Initiates to Support Information Management}

The information professionals are no longer to serve the communities by its traditional roles, waiting for the user to come, approach and consult them. Not anymore just to acquire, collect and manage the information within the organization, however, information professional is required to transform themselves from a document manager to knowledge managers (Hawamdeh \& Foo, 2001). In fact, the information professional will need to move from the local interaction to the wide range of collaboration and networking. To assume the roles of information professionals at the same time to encounter the rapid changes of the environments, thus, it is important for information professionals to enhance and expand their skills and competencies and leverage the information to increase the responsiveness on the dissemination of information (information capture, storage, retrieval and delivery) by embracing the technologies to support the information management activities in the organization. It is requiring the information professional to explore the technologies and has the ability to troubleshoot them, understand the Hypertext Markup Language (HTML), networking, computer language or script, discover the skills in translating the services into the online platform or ensure that they are always keeping up themselves with the emerging technologies (Ahmad \& Yaseen, 2009).

\section{User Educators to the Organization Including top Management}

The roles of the information professional require them to master at teaching skill in order to convince and influence the user is seeking and use the right information through various resources. Despite having a conventional style of teaching and face to face assistance, the information professional needs to be a user's educator and make teaching as the focus activities to engage the user. Typical information professions may expect the user to come and look for them at the desk. However, it must be changed now. In the new era, users will need to be approached and invited. As mentioned by Drummond (2016), it is critical for the information professional to put an extra effort into protecting their professions. This could be done by revamping and strengthen their teaching modules and activities, especially on information literacy as one of the core activities for information professionals. The user education activities including providing the instruction through the online tutorials, subject guides, research supports, user support, introduction video, guides to recommend the search engines for information retrieval and instruction in the area of information literacies. At Taylor's University, the top private universities in Malaysia, the Information Literacy has been 
absorbed as University Core Module (UCM) which will be offered to the first-year student and compulsory for Foundation and Degree programmes, to create awareness to the student on how to search and use the information effectively.

The student progress and achievement after the classes will be accessed through the quizzes and final examination. The liaison librarian who teaches the UCM will need to have a master's in library science and require applying for the teaching permit similar to the academician. Liu et al. (2016) in their case study found out that the student from the postgraduate level seen the importance of the user education programs, especially research guide to complete their thesis or final year project, the consultation and instructions on online databases. Erich and Popescu (2010) suggested three levels of the information literacy program at first level is to teach the student to familiarize themselves with the library operation, collections, systems and function of the library, the second level is the modules about how the information is organized and circulated, while the last level is all about information retrieval methods. Kirk (2004) suggested that the education of information literacy be extended to the senior leadership, the most skilled people to advise them on some problematic area that benefits the senior managers in the decision making and planning. It is important for the information specialist to ensure it is still relevant to the communities and find a better mechanism to approach its audience and make the teaching activities more interactive and valuable to the communities. It is because, according to Myburgh (2003), information professional should play a role through education to change the community mindset from different ideology by influencing them through the information.

\section{Research Assistant to the Faculties or Researchers to Support Long-life Learning}

Graduate from Information Management courses has been taught intensively on how to seek, manage, evaluate and use the information appropriately compared to others. With the skills, it makes information profession as one of the most significant contributions to the research and innovation made within the organization. Without the knowledge and subject matter expert like information professional, the researcher may not be able to capture the right material to support their paper and study, they might overlook some fact and model, or they might not be able to gather sufficient references. Information professional such as librarian will need to initiate the activity to engage with the researcher or the faculties to support lifelong learning, at the same time to develop their professional career. As a result, libraries are scoping, developing and implementing new role and service model especially in the area of research data (Brown et al, 2015). For example, in the educations environment, Library to collaborate with research centre by appointing the liaison librarian as a research assistant to the researcher in the centre, to support university research, whereby the librarian's other responsibilities in the Library is remained to be performed at the same time.

Appointing information professional as a research assistant will help the researcher to understand the technologies which nowadays is essential to find the information through the possible technology, and to deal with the big data. In fact, with the help of information professional as the research assistant will help the researcher to find valuable and quality information from trusted sources that may be helping them to produce an invention that no one knows about. According to Hart \& Kleinveldt (2011), the researchers top priority lists are to be kept been informed of new studies and finding in their field. Therefore, Schonfeld \& Housewright (2010) suggested that the information professional should be located together 
in the school or faculties, or the research unit to support the research activity. Dudko (2016) stated that adult is required to handle the technologies wisely as it changes the information environment faster and needs a thorough analysis of the value and content. Hence, the information professional should take this advantage to expand their boundaries and promote their capabilities to the broader environment to assist the researcher and to ensure the success of the study, the information professional need to remain knowledgeable and aware of the event and technologies surround them.

\section{Demonstrator of Information Management Policies, Procedures and Standards}

The information professional needs to maintain the awareness on the professional issues that are impacting their organization in this case libraries. Information professional will need to develop the information policies namely information literacy policies, policies related to access to the information, control of books, weeding policies and much more, then to demonstrate and executed the knowledge about the policies to its user. As mentioned by Basri et al., (2012) the information professional is the most suitable person to assist with the development of the information policies as they are handling most of the activities related to the information - acquiring, managing and reviewing the information. One of the initiatives that information professional may initiate is to develop a specialized subject guides and knowledge base, tutorial and guides or research support that might explain about the purpose of their organization or department towards information management. Yamazaki (2007) urged the information professional to focus on the service that only can be offered or catered by information professionals. In this case, information professional to assist with finding the most appropriate materials according to customers' requirement, evaluate and filter the information that they obtained.

At the same time, to fulfil the user's need and before supply, the information to the user, Hashim et al., (2017) urged that the trusted information agency needs to access and review the quality of the information to ensure the accuracy and relevancy of the information. It is recommended by Azemi et al., (2018) that to protect the quality of information, and the management must appoint the right and authorize an employee to source for the critical and helpful information as required. The services created and offered must be easily accessible at user convenience, most importantly, cost-effective information to the user. Information literacy, as one of the assets and core elements of the trusted information organization, especially in academic libraries, should have its own policies. Libraries should protect the content that has developed by the subject-matter expert or librarians. Documented it as policies and procedures, create a proper standard operating procedure (SOP), establish a standard of information management and produce a database to store the information and knowledge about the syllabus and content of user education activities. With the appropriate standard and policies, the information professional will help to explain and develop a deeper understanding of the data and information to the users and educate them to utilize the information available as a competitive tool.

Another responsibility of the information professional is to ensure the compliance of the standard, policies and law on the usage of the information by the user and safeguard the vital information in the organization. In order to be an expert in developing the policies and standard of information management, the information professional should be aware of the law and legislation related to the information management, current trends of information 
management without neglecting the past history of its so that the information professional conscious about the development of the information management and dynamic environment that impact the information management. Lord (2014) stated that one of the most significant problems is to demonstrate the value of information services. Still, the solution is to make the information professional's value more quantifiable and win new business. The information professional has to get everyone from all level to be involved and realizing the information management in the organization. This is to ensure that the information within the management is organised correctly and managed to boost efficient operation.

\section{Marketers of Library Services and Resources}

It is observed in the current situation that there are industries has come out with the services and technology that related to library services and resources; the closest is publishing industries. Working closely with the libraries or trusted information agencies, helping them to understand the nature of information professional job scope. By looking at these trends, it could consider as a threat or opportunities for the information professional to markets their roles in information management at the same time to promote the services and services to the user using the available channels. In most of the organization, the information professional job is seen to be replaced with the technologies. Moreover, due to the dynamic change of economic, cutting resources and budget become a common strategy to retain in the business. Other than that, librarian faces several challenges such as restrict funding and increase user expectation (Yi, 2016). Thus, some organization enforced that the department should find its own fund and income. For example, in most of the private universities, that they will initiate a program that in return, the cash or fund will flow to their department instead of the organizations.

Information professional that has all the knowledge about the information is encouraged to initiate the collaboration with the publishers or booksellers to be an instructor for the publications. Participate in the knowledge fair or publisher talks event either to be a speaker on specific topics or book reviews is another way for the information professional to market their professions and their expertise. Engagement with the CoP (Community of practice) to develop a relationship with another who has the same interest with is vital for this career. According to Drummond (2016), it is important to prove the information professional values of the people around you and promote what you can do. Another platform to market the resources and services offered by the information professional is through the website. It is essential for the information professional to be an advisor of all the content on their website. According to Mane \& Panage (2015), information professionals will carry with them the exclusive viewpoints and competencies while developing, planning and executing their web site's content, besides, they are knowledgeable in dealing with copyright issues, full commitment to the customer service and experience in producing the personalized the webbased information system. The information professional is required to find an initiative to make themselves and their product visible enough to be seen by its targeted user.

\section{Conclusion}

It is learnt that the roles of information professional tremendously changed and demanded. Thus it requires distinctive quality in this profession while dealing with the information. Sahu (2013) indicated that to face the challenge in the digital era, additional expertise and competencies within the information knowledge, technical and soft skills is a very much 
needed by the information professional to explore and conquered. A wide range of the skills is the key to help the information professional to transform from being conservative to the liberal, from traditional to modern. Information professional does have a great role in and remain to be a highly skilled in information retrieval and delivery, in minimizing the amount of time involved in sourcing the information and ensure the top quality of the outcome. Newton \& Dixon (1999) opined that the activities in the professions to be reviewed and renewed to compete with other professions that may perhaps overshadow information professional jobs. The strategy must be developed and planned to fulfil and negotiate the new roles and responsibilities, and support of the organization through the empowerment and motivation for personal development in improving the information professional's current and future career plans.

\section{Acknowledgement}

This article is financially supported by:

1. Faculty of Information Management, UiTM Selangor, Malaysia

\section{References}

Ahmad, P., \& Yaseen, M. (2009). The Role of the Library and Information Science Professionals as Managers: A Comparative Analysis. Electronic Journal of Academic and Special Librarianship. 10(3).

Azemi, N. A., Zaidi, H., \& Hussin, N. (2017). Information Quality in Organization for Better Decision-Making. International Journal of Academic Research in Business and Social Sciences, 7(12), 429-437.

Basri, M., Yusof, Z. M., \& Zin, N. A. M. (2012). Information policy: the diminishing role of library. International Journal of Humanities and Social Science, 2(19), 317-327.

Brown, R. A., Wolski, M., \& Richardson, J. (2015). Developing new skills for research support librarians. The Australian library journal, 64(3), 224-234.

Drummond, C. (2016). Embracing diversity: when is a librarian not a librarian?, The Australian Library Journal, 65(4), 274-279, DOI: 10.1080/00049670.2016.1233600

Dudko, S. A. (2016). The role of information technologies in lifelong learning development. SHS Web of Conferences, 29, 01019. DOI: 10.1051/shsconf/20162901019

Erich, A., \& Popescu, C. (2010). The impact of information literacy in the academic education environment. Library and Information Science, 14,150-161.

http://www.ceeol.com/aspx/getdocument.aspx?logid=5\&id=1b8c9554b2474a2f806c62b2b $06 \mathrm{~d} 2322$

Hart, G., \& Kleinveldt, L. (2011). The role of an academic library in research: Researchers' perspectives at a South African University of Technology. South African Journal of Libraries and Information Science. 77 (1), 37-50.

Hashim, H., Ismail, S. H., \& Hussin, N. (2017). Information Audit in Organization: A Library Perspective. International Journal of Academic Research in Business and Social Sciences, 7(8), 731-736.

Hawamdeh, S., \& Foo, S. (2001). Information professionals in the information age: Vital skills and competencies. Proc. International Conference for Library and Information Science Educators in the Asia Pacific Region (ICLISE 2001), Kuala Lumpur, Malaysia, June 11-12.

Kirk, J. (2004). Information and work: extending the roles of information professionals, presented at Challenging Ideas, ALIA 2004 Biennial Conference, Gold Coast, Queensland, 21-24 September, available at: 
www.conferences.alia.org.au/alia2004/pdfs/kirk.j.paper.pdf.

Liu, Q., Lo, P., \& Itsumura, H. (2016). Measuring the importance of library user education: a comparative study between Fudan University and the National Taiwan Normal University. The Journal of Academic Librarianship, 42(6), 644-654.

Lord, S. (2014). Closing the Gap: the Five Essential Attributes of the Modern Information Professional. Legal Information Management, 14(4), 258-265. DOI:10.1017/S1472669614000565

Mane, M., \& Pange, B. (2014). Development of Library Portal-In Print and Non-Print Era. International journal of advanced library and information science, 2(1), 121-125.

Newton, R., \& Dixon, D. (1999). New Roles for Information Professionals: User Education as a Core Professional Competency within the New Information Environment. Journal of Education for Library and Information Science, 40(3), 151-160. doi:10.2307/40324107

Sahu, M. K. (2013). Skill, Competences and Current Practice of Library Professionals in Engineering College Odisha: An Analytical Study. International Research: Journal of Library and Information Science, 3(4). http://irjlis.com/wpcontent/uploads/2013/12/4_IR153.pdf

Schonfeld, R. C., \& Housewright, R. (2010). Faculty survey 2009: Key strategic insights for libraries, publishers, and societies. New York: Ithaka $S+R$. [Online]. http://www.ithaka.org/ithaka-s-r/research/faculty-surveys-20002009/Faculty\%20Study\%202009.pdf

Myburgh, S. (2003). Education directions for new information professionals. The Australian Library Journal, 52(3), 213-227, DOI: 10.1080/00049670.2003.10721549

Yamazaki, H. (2007). Changing Society, Role of Information Professionals and Strategy for Libraries. IFLA Journal, 33(1), 50-58. https:doi.org/10.1177/0340035207076409

$\mathrm{Yi}$, Z. (2016). Effective techniques for the promotion of library services and resources. $I R$ Information Research. https://files.eric.ed.gov/fulltext/EJ1094561.pdf 